\title{
PENGARUH PENINGKATAN LAJU ENDAP DARAH TERHADAP HASIL PEMERIKSAAN FERITIN SERUM PADA IBU HAMIL
}

\author{
Gilang Nugraha ${ }^{1}$, Nur Masruroh ${ }^{2}$ \\ ${ }^{1}$ Prodi Analis Kesehatan, Fakultas Kesehatan \\ ${ }^{2}$ Prodi Kebidanan, Fakultas Keperawatan dan Kebidanan \\ Universitas Nahdlatul Ulama Surabaya \\ Email: gilang@unusa.ac.id
}

\begin{abstract}
Serum ferritin (SF) examination is a test parameter used to assess iron deposits in the body. SF examination has limitations, the degree is influenced by inflammation because ferritin is an acute phase protein. Elevated SF levels follow the increase in other acute phase proteins, the acute phase proteins of the gamma-globulin group to increase Erythrocyte Sedimentation Rate (ESR), as the proteins neutralize the membrane of the negatively charged erythrocytes Thus accelerating the ESR. Enhanced ESR can also be found in pregnant women, the increase in such ESR occurs during pregnancy. This research aims to determine whether there is an increase in ESR relation to SF examination results in pregnant women. The study used Cross sectional studies conducted in Puskesmas Jagir, Wonokromo, Surabaya City which was conducted in May 2019, with the samples of pregnant women research. Blood sampling is $6 \mathrm{~mL}$ and is accommodated as much as $3 \mathrm{~mL}$ on purple tubes for ESR inspection and $3 m L$ on red tubes for SF examination. Laboratory test results are conducted in correlation tests. A total of 30 pregnant women respondents participated in the study, an average age of 27 years and an average gestational age of 34 weeks. ESR inspection results are $56 \mathrm{~mm} / \mathrm{hr}$ (range: $27-117 \mathrm{~mm} / \mathrm{hr}$ ) and $S F 20 \mathrm{ng} / \mathrm{mL}$ test result (range: $2-149 \mathrm{ng} / \mathrm{mL}$ ). The correlation test result indicates that there is no increase in the ESR value of the SF level $(P=$ 0.240). It was concluded that the increase in ESR in pregnant women did not affect the results of SF examinations, increased due to hemodilution due to the physiological factor of pregnancy, resulting in decreased blood viscosity and increased blood erythrocyte sedimentation rate.
\end{abstract}

Keywords: Erythrocyte Sedimentation Rate, Feritin, Pregnant Women

\begin{abstract}
ABSTRAK
Pemeriksaan feritin serum (serum feritin, SF) adalah parameter pemeriksaan yang digunakan untuk menilai simpanan zat besi dalam tubuh. Pemeriksaan SF memiliki keterbatasan, kadarnya dipengaruhi oleh adanya peradangan karena feritin merupakan protein fase akut. Peningkatan kadar SF di ikuti dengan peningkatan protein fase akut lainnya, protein fase akut dari golongan gammaglobulin mampu meningkatkan Laju Endap Darah (LED), karena protein golongan tersebut menetralkan membran eritrosit yang bermuatan negatif sehingga mempercepat LED. Peningkatan LED juga dapat ditemukan pada wanita hamil, peningkatan LED tersebut terjadi selama kehamilan. Penelitian ini bertujuan menentukan ada tidaknya hubungan peningkatan LED terhadap hasil pemeriksaan SF pada wanita hamil. Penelitian menggunakan studi Cross sectional yang dilakukan di Puskesmas Jagir, Wonokromo, Kota Surabaya yang dilakukan pada bulan Mei 2019, dengan sampel penelitian wanita hamil. Dilakukan pengambilan darah sebanyak $6 \mathrm{~mL}$ dan ditampung
\end{abstract}


sebanyak $3 \mathrm{~mL}$ pada tabung ungu untuk pemeriksaan LED dan $3 \mathrm{~mL}$ pada tabung merah untuk pemeriksaan SF. Hasil pemeriksaan laboratorium dilakukan uji korelasi. Sebanyak 30 responden wanita hamil berpartisipasi dalam penelitian ini, umur rata-rata 27 tahun dan usia kehamilan ratarata 34 minggu. Hasil pemeriksaan LED $56 \mathrm{~mm} / \mathrm{jam}$ (rentang : 27 - $117 \mathrm{~mm} / \mathrm{jam}$ ) dan hasil pemeriksaan SF $20 \mathrm{ng} / \mathrm{mL}$ (rentang : 2 - $149 \mathrm{ng} / \mathrm{mL}$ ). Hasil uji korelasi menunjukkan bahwa tidak ada hubungan peningkatan nilai LED terhadap kadar SF $(\mathrm{P}=0,240)$. Disimpulkan bahwa peningkatan LED pada wanita hamil tidak mempengaruhi hasil pemeriksaan SF, peningkatan terjadi karena hemodilusi akibat faktor fisiologis kehamilan sehingga mengakibatkan viskositas darah menurun dan meningkatkan laju endap darah.

Kata kunci: Laju Endap Darah, Feritin, Wanita Hamil

\section{PENDAHULUAN}

Pemeriksaan feritin serum (serum feritin,

SF) adalah parameter pemeriksaan yang digunakan untuk menilai simpanan zat besi dalam tubuh. Feritin banyak ditemukan pada semua jaringan tubuh sebagai protein sitosol (intraseluler), kompleks protein yang membentuk feritin terdiri 24 sub unit dengan jenis sub-unit yaitu $\mathrm{H}$ (rantai berat) dan $\mathrm{L}$ (rantai ringan) dan saling berinteraksi dengan logam sehingga salah satu kemampuannya adalah mampu mengikat besi. ${ }^{1}$ Karena kemampuannya mengikat besi, feritin memiliki fungsi untuk menyimpan zat besi dalam tubuh. ${ }^{2}$

Pemeriksaan SF bersama-sama dengan pemeriksaan hematologi rutin, besi serum (serum iron, SI), kapasitas ikat besi total (total iron binding capasity, TIBC), saturasi transferin (transferin saturation, TS) dan hemoglobin retikulosit dihunakan untuk menetapkan status defisiensi besi. ${ }^{3}$ Defisiensi zat besi adalah masalah kesehatan global utama, kelompok risiko yang paling sering dilaporkan adalah individu yang kekurangan gizi, wanita hamil atau remaja, dan individu dengan kehilangan darah kronis. ${ }^{1}$ Dilaporkan bahwa wanita hamil yang kekurangan zat besi di Indoneisa mencapai 66,7\%. Jika dibaiarkan kondisi tersebut dapat berkembang menjadi anemia defisiensi besi yang dapat berdampak kematian ibu, kematian bayi, cacat bawaan, prematur, Badan Bayi Lahir Rendah (BBLR) dan anemia pada bayi yang dilahirkan. ${ }^{4}$

Pemeriksaan SF memiliki keterbatasan, kadarnya dipengaruhi oleh adanya peradangan karena feritin merupakan protein fase akut. Respon fase akut adalah reaksi pertahanan fisiologis utama, di mana tubuh bertujuan untuk mengembalikan homeostasis fisiologis dalam menghadapi peradangan. ${ }^{1}$ Artinya, peningkatan kadar feritin serum sebagai bagian dari respons fase akut berarti bahwa kadar feritin serum tidak lagi berkorelasi dengan ketersediaan zat besi dalam tubuh pada kasus peradangan.

Peningkatan kadar SF di ikuti dengan peningkatan protein fase akut lainnya seperti $C$ reactive protein, alpa-1-acid glycoprotein (AGP) yang dirangsang oleh interleukin, tumor 
necrosis factor-alpha, dan interferon gamma., Protein fase akut dari golongan gammaglobulin mampu meningkatkan laju endap darah, karena protein golongan tersebut menetralkan membran eritrosit yang bermuatan negatif sehingga mempercepat pembentukan rouleaux dan meningkatkan massa eritrosit. ${ }^{6}$ Peningkatan massa tersebut dapat meningkatkan laju eritrosit.

Pemeriksaan yang menilai laju endap eritrosit disebut Laju Endap Darah (LED), pemerikaan ini umumnya digunakan untuk deteksi dan memantau kerusakan jaringan atau infalamasi dan tidak menunjukkan adanya penyakit, sehingga pemeriksaan ini tidak bersifat spesifik. ${ }^{6}$ LED mengukur jarak plasma pada kolom tabung vertikal dalam satu jam. ${ }^{5}$ Selain kondisi patologis, peningkatan LED dapat terjadi akibat faktor tensi seperti kesalahan penggunaan antikoagulan, tabung yang miring selama pemeriksaan, temperatur dan guncangan selama proses pemeriksaan. ${ }^{6}$

Dilaporkan bahwa peningkatan LED juga dapat ditemukan pada wanita hamil, peningkatan LED terjadi selama kehamilan., Berdasarkan latar belakang tersebut, penelitian ini bertujuan menentukan ada tidaknya hubungan peningkatan LED terhadap hasil pemeriksaan SF pada wanita hamil.

\section{METODE PENELITIAN}

Penelitian menggunakan studi Cross sectional yang dilakukan di Puskesmas Jagir,
Wonokromo, Surabaya yang dilakukan pada bulan Mei 2019. Penelitian ini disetujui komisi etik Universitas Nahdlatul Ulama Surabaya dan melibatkan 30 responden wanita hamil. Informed consent diperoleh dari setiap responden secara individual. Kuesioner tertutup dilakukan untuk mendapatkan informasi usia, lama kehamilan, anak yang di kandung dan pendidikan terakhir. Kriteria inklusi penelitian adalah wanita hamil dan kriteria eksklusi hasil pemeriksaan hitung jumlah leukosit lebih dari 16.000/ $\mu$ L. $^{8}$ Sampel darah mengikuti protokol standar pengambilan dan penanganan sampel darah. Masing-masing responden wanita hamil, dilakukan pengambilan darah pada vena antecubiti dan di tampung menggunakan tabung BD Vacutainer ${ }^{\circledR}(13 \times 75 \mathrm{~mm})$ tutup merah yang tidak mengandung zat aditif sebanyak 3 $\mathrm{mL}$ dan tutup ungu yang mengandung antikoagulan EDTA sebanyak $3 \mathrm{~mL}$.

Darah pada tabung ungu dilakukan pemeriksaan hematologi untuk mendapatkan informasi jumlah leukosit menggunakan alat Sysmex XN-1000 (Sysmex Corporation Kobe, Jepang) dan pemeriksaan LED menggunakan alat Vision VC.0148 (Shenzhen YHLO Biotech Co., Ltd., Cina). Darah pada tabung merah dilakukan pemeriksaan serum feritin menggunakan alat Architect Ci8200 (Abbott Laboratories, USA). Pengambilan darah dan pemeriksaan laboratorium dilakukan di hari yang sama dan dilakukan di Laboratorium Pramita Jemurandayani Surabaya. 
Data dianalisis menggunakan SPSS. Data deskriptif disajikan sebagai nilai rerata, standar deviasi (SD), nilai minimum dan nilai maksimum. Uji korelasi Pearson dilakukan untuk menentukan hubungan antara nilai LED terhadap serum feritin. Nilai $\mathrm{P}<0,05$ dianggap signifikan.

\section{HASIL DAN PEMBAHASAN}

Sebanyak 30 responden wanita hamil berpartisipasi dalam penelitian ini, umur ratarata responden dalam penelitian ini 27 tahun dan rata-rata usia kehamilan 34 minggu. Sekitar $33 \%$ mengandung anak pertama, $43 \%$ mengandung anak kedua, 13\% mengandung anak ketiga, 7\% mengandung anak keempat dan 3\% mengandung anak kelima. Nilai ratarata hasil pemeriksaan LED pada wanita hamil didapat $56 \mathrm{~mm} / \mathrm{jam}$ (normal : 0-25 mm/jam) dan SF $20 \mathrm{ng} / \mathrm{mL}$ (normal : 10-150 ng/mL), hasil pemeriksaan secara terperinci dapat dilihat pada Tabel 1.

Tabel 1. Hasil pemeriksaan LED dan SF pada wanita hamil

\begin{tabular}{lccc}
\hline \multicolumn{1}{c}{$\begin{array}{c}\text { Parameter } \\
\text { Pemeriksaan }\end{array}$} & Mean & SD & Rentang \\
\hline $\begin{array}{l}\text { LED } \\
(\mathrm{mm} / \mathrm{jam})\end{array}$ & 56 & 20 & $27-117$ \\
\hline $\begin{array}{l}\text { Serum Feritin } \\
(\mathrm{ng} / \mathrm{mL})\end{array}$ & 20 & 27 & $2-149$ \\
\hline
\end{tabular}

Uji korelasi menunjukkan bahwa tidak ada hubungan peningkatan nilai LED terhadap kadar SF ( $\mathrm{P}=0,240)$, artinya peningkatan LED pada wanita hamil disebabkan oleh faktor di luar protein fase akut sehingga tidak mempengaruhi kadar SF dalam darah. Terdapat dua faktor yang mempengaruhi LED meningkat, yaitu faktor eritrosit dan faktor plasma. Eritosit yang memiliki masa dan luar permukaan yang besar dapat meningkatkan LED, sedangkan plasma meningkatkan LED akibat viskositas yang rendah. ${ }^{6}$

Dilaporkan bahwa selama proses kehamilan terjadi perubahan komposisi darah secara fisiologi. ${ }^{8,9}$ Selama kehamilan terjadi peningkatan volume darah sekitar 1,5 liter, peningkatan volume darah tersebut digunakan untuk memasok kebutuhan darah janin dan kompensasi kehilangan darah saat melahirkan. Volume darah yang meningkat didominasi plasma, peningkatan volume plasma sekitar $10 \%$ sampai $15 \%$ dan dimulai dari 6 sampai 12 minggu kehamilan. Selain peningkatan volume plasma, eritrosit juga mengalami peningkatan, tetapi relatif lebih sedikit jika dibandingkan dengan volume plasma. $^{9}$ Oleh karena jumlah volume plasma lebih banyak dibandingkan volume eritrosit, maka terjadi hemodilusi yang ditandai dengan penurunan nilai hematokrit. Penurunan kadar hematorit sebagai indikator penurunan viskositas darah dan penurunan viskositas darah meningkatkan LED.

Faktor lain yang meningkatkan LED adalah komposisi eritrosit dalam darah menurun. Diketahui bahwa proses pengendapan darah terjadi dalam tiga tahap. Tahap pertama adalah tahap di mana eritrosit 
mengalami agregasi dan membentuk tumpukan yang dikenal dengan formasi rouleaux, proses ini terjadi selama 10 menit pertama. Tahap kedua adalah tahap di mana eritrosit mengalami pengendapan cepat dan terjadi 40 menit berikutnya. Tahap ketiga adalah tahap di mana eritrosit mengisi celah-celah pada tumpukan eritrosit di bawah tabung, proses ini terjadi selama 10 menit. ${ }^{6}$ Jumlah eritrosit yang sedikit akan memudah-kan pengendapan, karena tidak terhalangi oleh eritrosit lain untuk mengendap. Selain itu, jumlah eritrosit yang sedikit dapat memudah-kan pengisian celah pada tumpukan eritrosit sehingga menyebabkan LED meningkat.

Perubahan komposisi pada darah tidak hanya terjadi pada komponen eritrosit dan plasma, tetapi diikuti oleh peningkatan leukosit dan penurunan trombosit. Peningkatan leukosit selama kehamilan terjadi karena tekanan fisiologis. Penurunan jumlah trombosit disebabkan karena hemodilusi, peningkatan aktivitas trombosit dan pencepatan pembersihan trombosit dalam sirkulasi dalam darah selama kehamilan. ${ }^{6}$ Akan tetapi perubahan komposisi leukosit dan trombosit belum pernah dilaporkan mampu meningkatkan LED.

Mekanisme tersebut berbeda pada peningkatan LED pada kasus peradangan. Peradangan seperti infeksi, trauma, radang sendi akut, gangguan autoimun spesifik atau neoplasma akan menstimulasi sitokin proinflamasi seperti interleukin (IL)-6, IL-1, tumornecrosis factor-alpha dan interferon gamma yang dihasilkan monosit, makrofag dan sel-sel lain. Sitokin-sotokin yang diproduksi merangsang pembentukan reaktan fase akut termasuk SF. ${ }^{5}$ Beberapa protein yang dihasilkan bermuatan positif dan menetralkan eritrosit yang bermuatan negatif, sehingga gaya tolak menolak eritrosit akan hilang dan akan mudah membentuk rouleaux dengan massa yang menjadi lebih tinggi sehingga eritrosit mudah mengendap. ${ }^{6}$

\section{SIMPULAN DAN SARAN}

Peningkatan LED pada wanita hamil tidak mempengaruhi hasil pemeriksaan SF. Peningkatan LED terjadi karena hemodilusi yang terjadi akibat faktor fisiologis kehamilan, mengakibatkan viskositas darah menurun dan meningkatkan laju endap darah.

Tidak perlu ada kekhawatiran penggunaan parameter SF guna menegakan diagnosa defisiensi besi pada wanita hamil dengan nilai LED tinggi. Perlunya penambahan parameter lain untuk membedakan LED tinggi akibat peradangan atau bukan peradangan, seperti CRP agar kualitas pemeriksaan SF tetap terjaga.

\section{REFERENSI}

1. Dignass A, Farrag K, Stein J. Limitations of Serum Ferritin in Diagnosing Iron Deficiency in Inflammatory Conditions. Int J Cronic Dis. 2018;2018:1-11. 
2. Saito H. Metabolism of Iron Stores. Nagoya J Med Sci [Internet]. 2014;76(3-4):235-54. Available from: http://www.ncbi.nlm.nih.gov/ pubmed/25741033\%0Ahttp://www.pubmed central.nih.gov/articlerender.fcgi?artid=PM C4345694

3. Daru J, Colman K, Stanworth SJ, Salle BD La, Wood EM, Pasricha S. Serum ferritin as an indicator of iron status: what do we need to know? Am J Clin Nutr. 2017;106(Suppl):1634-9.

4. Roosleyn IPT. Strategi dalam Penanggulangan Pencegahan Anemia pada Kehamilan. J Ilm Widya. 2016;3(3):1-9.

5. Markanday A. Acute Phase Reactants in Infections : Evidence- Based Review and a Guide for Clinicians. Open forum Infect Desease. 2015;2(3):1-7.

6. Nugraha G. Panduan Pemeriksaan Laboratorium Hematologi Dasar. Ke-2. Jakarta: Trans Info Media; 2017.

7. Broek NR Van Den, Letsky EA. Pregnancy and the erythrocyte sedimentation rate. $\mathrm{Br} \mathrm{J}$ Obstet Gynaecol. 2001;108:1164-7.

8. Mutua DN, Nyaga E, Njagi M, Orinda GO. Hematological Profile of Normal Pregnant Women. J Blood Lymph. 2018;8(2):1-6.

9. Chandra S, Kumar A, Cells RB. Physiological Changes in Hematological Parameters During Pregnancy. Indian J Hematol Blood Transfus. 2012;28(3):1446. 